\title{
PENGARUH LOKASI TERHADAP KEPUASAN PELANGGAN MELALUI KEPUTUSAN PEMBELIAN PERUMAHAN THE ANGGANA PT ADHI PERSADA PROPERTY JAKARTA
}

\author{
Bongsu Saragih *) \\ *) Dosen Program Studi Manajemen FE UNKRIS \\ Alamat: Kampus UNKRIS, Jatiwaringin Jakarta Timur \\ Email:bongsu.saragih@gmail.com
}

\begin{abstract}
This study aims to determine and analyze the influence of location on purchasing decisions, knowing and analyzing the influence of location on customer satisfaction, knowing purchasing decisions on customer satisfaction, knowing the effect of location on customer satisfaction through customer decisions. The analysis shows that location influences purchasing decisions, which means that the more location strategy can improve purchasing decisions. Location affects customer satisfaction, which means that locations that are easily accessible can increase customer satisfaction. Purchasing decisions affect customer satisfaction, which means that consumers will feel satisfied if there is compatibility. Location influences customer satisfaction through purchasing decisions, which means that strategic location can increase customer satisfaction if purchasing decisions are made rationally.
\end{abstract}

Keywords: Location, purchase decision, customer satisfaction

\section{PENDAHULUAN}

Kepuasan pelanggan memberikan banyak keuntungan bagi perusahaan dimana salah satu yang penting yaitu memungkinkan tercapainya loyalitas pelanggan (Lovelock, 2005). Sejalan dengan kompetisi merebut pelanggan property dan semakin meningkatnya kebutuhan manusia akan tempat tinggal (landed house), maka sebuah produk harus bisa memuaskan pelanggan. Pelanggan yang puas bisa bercerita pada rekan, saudara, dan familinya sehingga ikut menggaet pembeli selanjutnya. Pelanggan yang puas bisa juga melakukan pembelian rumah kedua, dan ketiga pada lokasi tersebut sebagai wujud investasi.

Pasar properti selalu berkembang secara volume dari tahun ke tahun, dimana ditentukan oleh besaran penawaran dan permintaan, sehingga secara langsung akan mempengaruhi harga. Keinginan memiliki rumah ditentukan oleh daya beli calon pelanggan, sehingga kemampuan individu dalam pembiayaan bisa mempengaruhi keputusan pemilihan type unit dan spesifikasi rumah. Ketelitian calon pelanggan dalam mengumpulkan informasi dan cara pembiayaan juga bisa mempengaruhi dalam keputusan pembelian.

Kebutuhan akan tempat tinggal bagi penduduk Indonesia dari tahun ke tahun mengalami peningkatan sedangkan luasan tanah tersedia di muka bumi tidak pernah bertambah luas. Untuk pembangunan landed house di wilayah Jakarta makin susah, maka pemenuhan hunian warga Jakarta sebagian dipenuhi dengan penyediaan 
hunian di wilayah penyangga (Bogor, Bekasi, dan Tangerang).

Tabel 1: Capaian Program Satu Juta Rumah

\begin{tabular}{cc}
\hline Tahun & $\begin{array}{c}\text { Jumlah Pembangunan } \\
\text { Rumah }\end{array}$ \\
\hline 2015 & 699.770 unit \\
2016 & 805.169 unit \\
2017 & 904.758 unit \\
2018 & 1.132 .621 unit \\
\hline \multicolumn{2}{c}{ Mencermati adanya peluang } \\
bisnis hunian (property) di Kabupaten \\
Bogor.
\end{tabular}

Salah satu pelaku bisnis properti di Indonesia, adalah PT. Adhi Persada Property, anak perusahaan PT ADHI KARYA (Persero). Pada tahun 2018 PT. APP meluncurkan produk The Anggana Village di Cibinong. Berangkat dari latar belakang, penelitian ini membahas pengaruh lokasi terhadap kepuasan pelanggan melalui keputusan pembelian. Penelitian ini bertujuan untuk mengetahui dan menganalisa pengaruh lokasi terhadap kepuasan pelanggan melalui keputusan pembelian

\section{LANDASAN TEORI}

\section{Lokasi}

Alma (2003) mengemukakan bahwa lokasi adalah tempat perusahaan beroperasi atau tempat perusahaan melakukan kegiatan untuk menghasilkan barang dan jasa yang mementingkan segi ekonominya. Menurut Suwarman (2004), lokasi merupakan tempat usaha yang sangat mempengaruhi keinginan seseorang pelanggan untuk datang dan berbelanja. Selanjutnya pengertian lokasi menurut Kasmir (2009) yaitu tempat melayani pelanggan, dapat pula diartikan sebagai tempat untuk memajangkan barangbarang dagangannya. Tjiptono (2002) mendefinisikan lokasi adalah tempat perusahaan beroperasi atau tempat perusahaan melakukan kegiatan untuk menghasilkan barang dan jasa yang mementingkan segi ekonominya.

$$
\text { Menurut Tjiptono }
$$
pemilihan tempat atau lokasi fisik memerlukan pertimbangan cermat terhadap faktor-faktor berikut: 1). Akses, misalnya lokasi yang dilalui atau mudah di jangkau sarana transfortasi umum. 2). Visibilitas, yaitu lokasi atau tempat yang dapat dilihat dengan jelas dari jarak pandang normal. 3). Lalu lintas (traffic), menyangkut dua pertimbangan utama: a). Banyaknya orang yang lalu-lalang bisa memberikan peluang besar terhadap terjadinya buying, yaitu keputusan pembelian yang sering terjadi spontan, tanpa perencanaan, dan atau tanpa melalui usaha-usaha khusus. b). Kepadatan dan kemacetan lalu lintas bisa juga jadi hambatan. 4). Tempat parkir yang luas, nyaman, dan aman, baik untuk kendaraan roda dua maupun roda empat. 5). Ekspansi, yaitu tersedianya tempat yang cukup luas apabila ada perluasan di kemudian hari. 6). Lingkungan, yaitu daerah sekitar yang mendukung produk yang ditawarkan. Sebagai contoh, restoran/ rumah makan berdekatan dengan daerah pondokan, asrama, mahasiswa kampus, sekolah, perkantoran, dan sebagainya. 7). Persaingan, yaitu lokasi pesaing. Sebagai contoh, dalam menentukan lokasi restoran, perlu dipertimbangkan apakah dijalan/daerah yang sama terdapat restoran lainnnya. 8). Peraturan pemerintah, misalnya ketentuan yang melarang rumah makan berlokasi terlalu berdekatan dengan pemukiman penduduk/tempat ibadah. Menurut Tjiptono (2006) indikator lokasi meliputi : 1). Keterjangkauan lokasi. 2). Kelancaran akses menuju lokasi. 3). Kedekatan lokasi. 


\section{Keputusan Pembelian}

Sebelum pelanggan memutuskan untuk membeli, biasanya pelanggan melalui beberapa tahap terlebih dahulu yaitu, 1). Pengenalan masalah, 2). Pencarian informasi. 3). Evaluasi alternatif, 4). Keputusan membeli atau tidak, 5). Perilaku pascapembelian. Pengertian lain tentang Keputusan pembelian menurut Schiffman dan Kanuk (2000) adalah "the selection of an option from two or alternative choice". Dapat diartikan, keputusan pembelian adalah suatu keputusan seseorang dimana dia memilih salah satu dari beberapa alternatif pilihan yang ada. Selanjutnya Amirullah (2002) menyatakan keputusan pembelian adalah suatu proses penilaian dan pemilihan dari berbagai alternatif sesuai dengan kepentingan-kepentingan tertentu dengan menetapkan suatu pilihan yang dianggap paling menguntungkan.

Berdasarkan definisi tersebut, disimpulkan bahwa keputusan pembelian adalah tindakan yang dilakukan pelanggan untuk melakukan pembelian sebuah produk. Oleh karena itu, pengambilan keputusan pembelian pelanggan merupakan suatu proses pemilihan salah satu dari beberapa alternatif penyelesaian masalah dengan tindak lanjut yang nyata. Setelah itu pelanggan dapat melakukan evaluasi pilihan dan kemudian dapat menentukan sikap yang akan diambil selanjutnya.

Kotler (2007) mengemukakan bahwa terdapat indikator dari keputusan pembelian, yaitu: 1). Kemantapan pada sebuah produk adalah Kualitas produk yang sangat baik akan membangun kepercayaan pelanggan sehingga merupakan penunjang kepuasan pelanggan. 2). Memberikan rekomendasi kepada orang lain adalah memberikan kepada seseorang atau lebih bahwa sesuatu yang dapat dipercaya, dapat juga merekomendasikan diartikan sebagai menyarankan, mengajak untuk bergabung, menganjurkan suatu bentuk perintah. 3). Melakukan pembelian ulang, Pengertian pembelian ulang adalah individu melakukan pembelian produk atau jasa dan menentukan untuk membeli lagi, maka pembelian kedua dan selanjutnya disebut pembelian ulang.

\section{Kepuasan Pelanggan}

Menurut Kotler dan Keller (2013), pengertian kepuasan pelanggan adalah tingkat keadaan perasaan seseorang yang merupakan hasil perbandingan antara penilaian kinerja atau hasil akhir produk dalam hubungannya dengan harapan pelanggan. "Satisfaction is the function of the closeness between expectations and the product's perceived performance. If performance falls short of expectations, the consumer is dissapointed; if it meets expectations, the consumer is satisfied; if it exceeds expectations, the consumer is delighted".

Menurut Tjiptono (2008) ada beberapa strategi yang dapat dipadukan untuk meraih dan meningkatkan kepuasan pelanggan, diantaranya: 1). Strategi relationship marketing, yaitu strategi dimana transaksi pertukaran antara pembeli dan penjual berkelanjutan, tidak berakhir setelah penjualan selesai. 2). Strategi superior customer service, yaitu menawarkan pelayanan yang lebih baik dari pesaing, maksud disini adalah bentuk-bentuk layanan yang mungkin dikembangkan oleh sebuah perusahaan meliputi garansi, jaminan pelatihan cara penggunaan produk, konsultasi teknikal, reparasi, penyediaan suku cadang, informasi berkala perusahaan dan sebagainya. 3). Strategi unconditional service guarantees, strategi ini berintikan komitmen untuk memberikan 
garansi atau jaminan istimewa atau mutlak yang dirancang untuk meringankan risiko kerugian pelanggan, dalam hal pelanggan tidak puas dengan suatu produk atau jasa yang telah dibayarnya. Garansi tersebut berfungsi untuk mengurangi risiko pelanggan sebelum dan sesudah pembelian barang atau jasa, sekaligus memaksa perusahaan bersangkutan untuk memberikan yang terbaik dan meraih loyalitas pelanggan. 4). Strategi penanganan keluhan yang efektif, penanganan keluhan memberikan peluang untuk mengubah pelanggan yang tidak puas menjadi pelanggan yang puas.

Indikator pelanggan menurut Tjiptono (2008) adalah sebagai berikut: 1). Kesesuaian harapan; Merupakan gabungan dari kemampuan suatu produk atau jasa dan promosi yang diandalkan, sehingga suatu produk yang dihasilkan dapat sesuai dengan apa yang dijanjikan produsen. b). Kemudahan dalam memperoleh; Produk atau jasa yang ditawarkan oleh produsen tersedia di outlet-outlet dan toko yang dekat dengan pembeli potensial. c). Kesediaan untuk merekomendasi; Kesediaan pelanggan untuk merekomendasikan produk atau jasa kepada teman atau keluarganya menjadi ukuran yang penting untuk dianalisis dan ditindak.

\section{Kerangka Konseptual Penelitian}

Berdasarkan latar belakang, maka kerangka konseptual dalam penelitian ini adalah sebagai berikut:

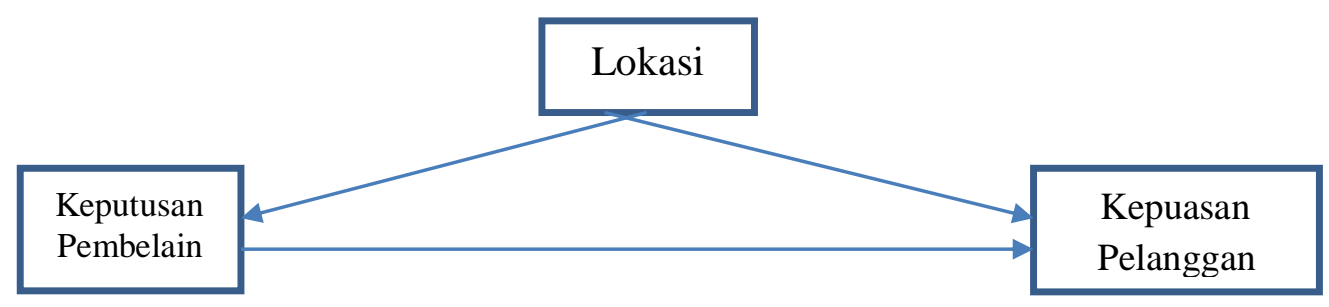

Gambar 1: Kerangka Konseptual

\section{METODE PENELITIAN}

Penelitian ini merupakan penelitian kausal, yang bertujuan mencari sebab dan akibat. yaitu: 1). Mencari penyebab dan variabel pengaruh (variable independent) dan variabel yang menjadi akibat atau variabel terpengaruh (variable dependent). 2). Mengetahui hubungan atau keterkaitan antara variabel-variabel tersebut.

Populasi dalam penenlitian ini adalah kelompok pelanggan dan calon pelanggan PT. Adhi Persada Properti. Obyek penelitian adalah Anggana the Village - Cibinong. Sampai dengan saat ini jumlah pelanggan yang telah melakukan pembayaran booking fee atau sepakat melakukan perjanjian pembelian rumah (SPR) mencapai 30\% (113 orang), sedangkan calon pembeli yang sedang diprospek dan follow up, 100 orang. Calon pembeli yang sudah mengunjungi open table, call in, walk in, canvas, dan pameran berjumlah 4.767 orang.

Sampel yang digunakan adalah jumlah pelanggan yang telah melakukan pembayaran booking fee atau sepakat melakukan perjanjian pembelian rumah (SPR) mencapai $30 \%$ atau 113 orang. Teknik pengumpulan data yang digunakan adalah metode survei. Dengan demikian dalam penelitian ini akan mengumpulkan data dari pelanggan PT. 
Adhi Persada Properti. Prosedur pengumpulan data yang digunakan dalam penelitian ini adalah pengumpulan data terstruktur (structured data collection), yaitu pengumpulan data melalui penyampaian kuesioner formal yang menyajikan pertanyaan-pertanyaan yang telah disusun teratur terlebih dahulu (Malhotra dan Dash, 2009). Studi survei: a) Pengamatan (observation) secara langsung terhadap fasilitas, lokasi dan lingkungan perumahan: b) Wawancara dengan bertanya langsung kepada staf dan karyawan bagian pemasaran. c) Kuesioner yaitu daftar yang berisi pertanyaan - pertanyaan untuk diisi oleh para responden. 2). Studi dokumentasi, mengumpulkan data dan informasi dari buku-buku, jurnal dan internet yang berkaitan dengan penelitian.

Agar data yang dikumpulkan dapat bermanfaat, harus diolah dan dianalisis terlebih dahulu sehingga dapat dijadikan sebagai dasar dalam pengambilan keputusan. Analisis data yang digunakan dalam penelitian ini adalah analisis kuantitatif. Pada penelitian kuantitatif kegiatan analisis datanya meliputi pengolahan data dan penyajian data, melakukan perhitungan untuk mendeskripsikan data dan melakukan pengujian hipotesis dengan menggunakan uji statistik (Sofyan, 2013).

\section{HASIL PENELITIAN DAN PEMBAHASAN}

\section{Hasil Penelitian}

Hasil uji validitas dan hasil uji reliabilitas

Pengujian validitas dilakukan dengan membandingkan nilai r-hitung dengan r-tabel untuk tingkat signifikansi 5 persen dari degree of freedom $(\mathrm{df})=\mathrm{n}$ 2, dalam hal ini (n) adalah jumlah sampel. Jika r-hitung > r-tabel, maka pernyataan atau indikator tersebut dinyatakan valid, demikian sebaliknya bila r-hiung < r-tabel, maka pernyataan atau atau indikator tersebut dinyatakan tidak valid. Hasil perhitungan koefisien korelasi skor tiap butir pernyataan dari 113 sampel responden variabel lokasi dengan jumlah pernyataan sebanyak 3 pernyataan, variabel keputusan pembelian dengan jumlah pernyataan sebanyak 3 pernyataan, variabel kepuasan pelanggan dengan jumlah pernyataan sebanyak 3 pernyataan. Seluruh butir pernyataan pada variabel lokasi, variabel keputusan pembelian dan variabel kepuasan pelanggan hasilnya valid (r-hitung > r-tabel).

$$
\text { Selanjutnya dilakukan uji }
$$

reliabilitas untuk mengetahui sejauhmana pengukurannya dapat diandalkan dan konsisten, sedangkan uji reliabilitas pada kesempatan penelitian ini dilakukan dengan menggunakan formula Alpha Cronbach. Formula ini merupakan prosedur pencarian nilai reliabilitas dengan tidak mensyaratkan pembelahan item ke dalam dua kelompok, selanjutnya hasil pengukuran dengan formula Alpha Cronbach akan dibandingkan dengan nilai standar reliabilitas dengan kesalahan (5\%), hal ini didasarkan pendapat Nunnaly (2005). Diketahui bahwa jika semua variabel mempunyai alpha di atas 0,60 berarti semua variabel dapat diandalkan. Berikut ini adalah uji reliabilitas dari masingmasing variabel penelitian yang dilakukan. 
Tabel 2: Hasil Uji Reliabilitas Variabel

\begin{tabular}{lcc}
\hline \multicolumn{1}{c}{ Variabel } & Cronbach's Alpha & Keterangan \\
\hline Lokasi & 0.730 & Reliabel \\
Keputusan Pembelian & 0.735 & Reliabel \\
Kepuasan Pelanggan & 0.779 & Reliabel \\
\hline
\end{tabular}

Sumber: Hasil pengolahan data, 2019

Dari Tabel 2, diketahui bahwa nilai Cronbach's Alpha variabel lokasi adalah 0,730, variabel keputusan pembelian adalah 0,735 , dan variable kepuasan pelanggan adalah 0,779 . Nilai tersebut lebih besar dari 0,60 , artinya bahwa seluruh pernyataan pada variabel bersifat reliabel.

Analisis jalur (path analysis)

Nilai $R^{2}$ ( $R$ Square) sebesar 0,580 . Nilai $R^{2}$ ini digunakan dalam penghitungan nilai koefisien $\mathrm{e}_{1}$. Koefisien $\mathrm{e}_{1}$ merupakan varian keputusan pembelian yang tidak dijelaskan oleh lokasi Besarnya

koefisien $\mathrm{e}_{1}=\sqrt{\left(1-R^{2}\right)}=$
$\sqrt{(1-0,580)}=\sqrt{0,420}=0,648$. berikut:

Persamaan regresi sebagai

$$
\begin{aligned}
& Y_{1}=b_{1} X_{1}+e_{1} \\
& Y_{1}=0,353 X_{1}+0,285
\end{aligned}
$$

Persamaan tersebut menunjukkan bahwa setiap terjadi peningkatan 1 satuan lokasi, akan diikuti peningkatan keputusan pembelian sebesar 0,353, sehingga dari persamaan (1) dapat diketahui bahwa jika lokasi meningkat maka keputusan pembelian akan meningkat. Begitu juga dengan harga, jika harga meningkat maka keputusan pembelian juga akan ikut meningkat.

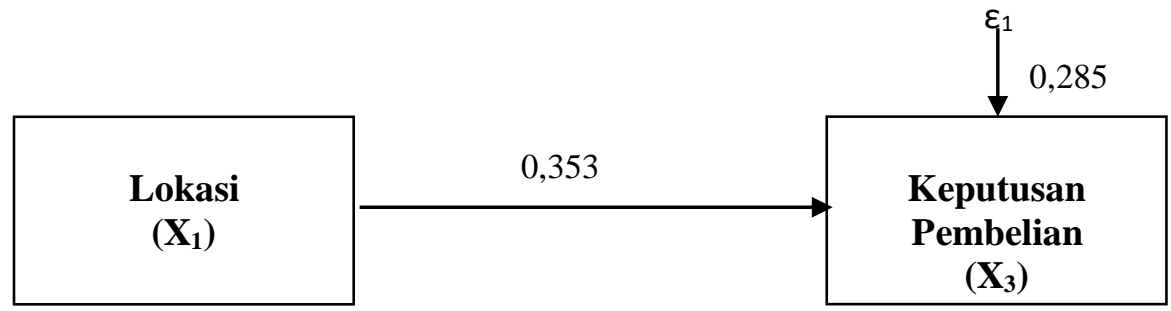

\section{Gambar 2: Persamaan Substruktur 1}

Nilai $\mathrm{R}^{2}$ (R Square) sebesar 0,642. Nilai $\mathrm{R}^{2}$ ini digunakan dalam penghitungan nilai koefisien $\mathrm{e}_{2}$. Koefisien $\mathrm{e}_{2}$ merupakan varian kepuasan pelanggan yang tidak dijelaskan oleh harga, lokasi dan keputusan pembelian. Besarnya koefisien $\mathrm{e}_{2}=\sqrt{\left(1-R^{2}\right)}=\sqrt{(1-0,642)}=$ $\sqrt{0,358}=0,598$.

berikut:

$$
\begin{aligned}
& Y_{2}=b_{1} X_{1}+b_{2} Y_{1}+e_{2} \\
& Y_{2}=0,261 X_{1}+0,259 Y_{1}+0,598 e_{2} .
\end{aligned}
$$

Persamaan tersebut menunjukkan bahwa: 1). Setiap terjadi peningkatan 1 satuan lokasi, akan diikuti peningkatan kepuasan pelanggan sebesar 0,261. 2). Setiap terjadi peningkatan 1 satuan keputusan pembelian, akan diikuti peningkatan kepuasan pelanggan sebesar 0,259, sehingga dari persamaan (2) dapat diketahui bahwa jika lokasi meningkat maka kepuasan pelanggan 
akan meningkat.. Begitu juga dengan keputusan pembelian, jika keputusan pembelian meningkat maka kepuasan pelanggan juga akan ikut meningkat.
Berdasarkan $_{1}$ persamaan $_{1}$ (1) dan (2) didapat suatu model analisis jalur sebagai berikut.

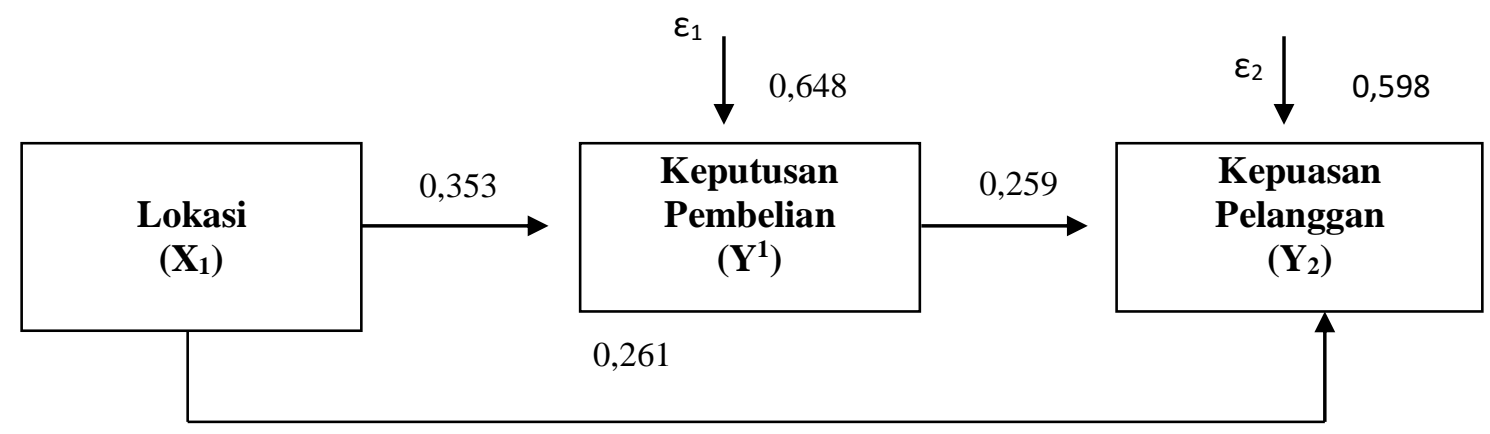

Gambar 3 Model Analisis Jalur

Hasil analisis pengaruh lokasi terhadap kepuasan pelanggan melalui keputusan pembelian berdasarkan perhitungan dengan analisis jalur pada Gambar 3 (Model Analisis Jalur) adalah:

$$
\mathrm{X}_{1} \rightarrow \mathrm{Y}_{1} \rightarrow \mathrm{Y}_{2}=\left(\rho \mathrm{X}_{1} \mathrm{Y}_{1}\right)
$$

$$
\mathrm{x}\left(\rho \mathrm{Y}_{1} \mathrm{Y}_{2}\right)
$$

Nilai pengaruh tidak langsung diperoleh dari nilai koefisien jalur $\rho \mathrm{X}_{1} \mathrm{Y}_{1}$ dikalikan dengan nilai koefisien jalur $\rho \mathrm{Y}_{1} \mathrm{Y}_{2}$ menjadi $(0,353 \times 0,259)=0,126$. Hasil perkalian menunjukkan bahwa nilai koefisien berpengaruh tidak langsung adalah sebesar 0,126. Sedangkan nilai pengaruh langsung antara $\rho X_{1} Y_{2}$ adalah sebesar 0,261 . Hal ini menunjukkan bahwa nilai pengaruh tidak langsung lebih kecil dibandingkan nilai koefisien pengaruh langsung yaitu $(0,126<0,261)$ dan pengaruh total sebesar $0,261+0,126=0,512$.

Berdasarkan hasil analisis jalur tersebut menunjukkan bahwa variabel lokasi dapat melalui variabel mediasi yaitu keputusan pembelian dalam mempengaruhi kepuasan pelanggan, karena nilai pengaruh total lebih besar dibandingkan pengaruh langsung.

Analisis jalur lokasi terhadap kepuasan pelanggan melalui keputusan pembelian dapat digambarkan sebagai berikut.

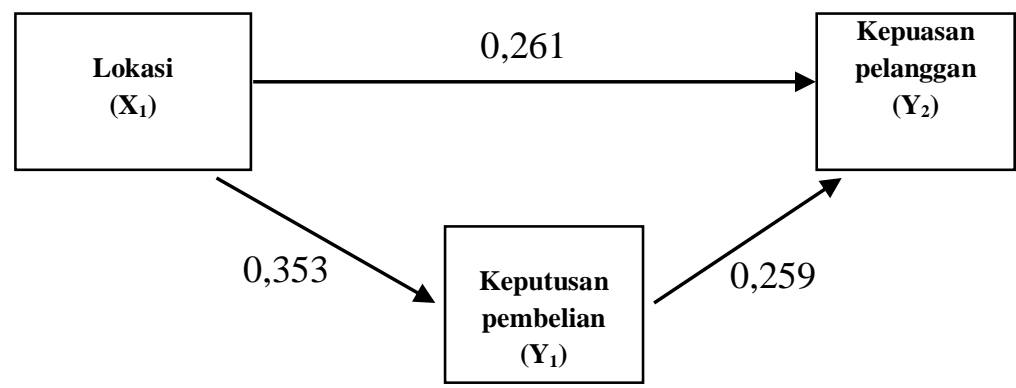

$$
0,353 \times 0,259=0,126
$$

Gambar 4 Analisis Jalur Pengaruh $X_{1}$ terhadap $Y_{2}$ Melalui $Y_{1}$ 


\section{Pembahasan}

\section{Pengaruh lokasi terhadap keputusan Pembelian}

Lokasi berpengaruh terhadap keputusan pembelian, yang berarti bahwa semakin baik lokasi perumahan The Anggana by Adhi di Pakansari Cibinong Kabupaten Bogor dapat meningkatkan keputusan pembelian. Hal ini menunjukkan bahwa lokasi yang tingkat kemacetan lalu lintas rendah, rute jalur menuju tempat kerja tidak membutuhkan waktu yang lama dan jalan akses menuju obyek umum (RSU, swalayan, wisata, sekolah, dan pemda) tidak jauh berdampak pada peningkatan keputusan pembelian. Oleh karena itu kebutuhann akan rumah bukan hanya tempat berlindung tetapi memiliki fungsi yang beragam seperti lokasi yang strategis. Sebagaimana pendapat Tresnanda et al. (2014) yang menyatakan bahwa pemilihan lokasi merupakan faktor bersaing yang penting dalam usaha menarik pelanggan atau pelanggan. Semakin strategis letak perumahan The Anggana by Adhi di Pakansari Cibinong Kabupaten Bogor berarti semakin baik dan memiliki tingkat permintaan yang semakin tinggi. Faktor-faktor ekonomi dari keberadaan lokasi perumahan juga menjadi pertimbangan pelanggan dalam memilih rumah yang dikehendakinya. Jarak menuju tempat kerja, tempat hiburan, dan fasilitas umum sebagai motif efesiensi waktu dan biaya transportasi merupakan faktor ekonomi yang menjadi pertimbangan pelanggan di dalam memilih lokasi rumah yang dimaksud (Dengah et al, 2013). Hasil penelitian ini mendukung Syuhada (2013) yang menyatakan bahwa lokasi berpengaruh terhadap keputusan pembelian.

\section{Pengaruh lokasi terhadap kepuasan pelanggan}

Lokasi berpengaruh terhadap kepuasan pelanggan, yang berarti bahwa semakin strategis perumahan The Anggana by Adhi di Pakansari Cibinong Kabupaten Bogor dapat meningkatkan kepuasan pelanggan. Lokasi yang tepat akan sangat memberikan kepuasan pelanggan, karena lokasi merupakan bagian penting dalam menentukan tempat tinggal. Lokasi usaha biasanya bisa menjadi sasaran atau tujuan yang tepat bagi pelanggan. Pelanggan akan puas dengan lokasi perumahan apabila lokasi perumahan yang pelanggan beli memiliki tingkat kemacetan lalu lintas rendah, rute jalur menuju tempat kerja tidak membutuhkan waktu yang lama dan jalan akses menuju obyek umum (RSU, swalayan, wisata, sekolah, dan pemda) tidak jauh.

\section{Pengaruh Keputusan Pembelian terhadap Kepuasan Pelanggan}

Keputusan pembelian berpengaruh terhadap kepuasan pelanggan. Keputusan pembelian merupakan tindakan dari pelanggan untuk mengambil keputusan membeli atau tidak terhadap suatu produk. Pelanggan biasanya selalu mempertimbangkan dari segi kualitas produk, harga, dan promosi. Pelanggan akan mengalami tingkat kepuasan apabila barang yang didapat sesuai dengan kebutuhan dan keinginan. Sebaliknya, pelanggan akan memiliki ketidakpuasan setelah melakukan pembelian jika barangnya tidak sesuai harapan. Sebelum pelanggan mengambil keputusan pembelian, seorang pelanggan membuat beberapa pertimbangan. Untuk sampai kepada keputusan pembelian seorang pelanggan melaui tahap proses keputusan pembelian. Keputusan membeli atau tidak akan suatu produk, lebih-lebih dalam pembelian rumah untuk keperluan orang banyak, maka 
akan memerlukan banyak orang yang ikut campur dalam proses pengambilan keputusan.

\section{Pengaruh lokasi terhadap kepuasan pelanggan melalui kepuasan pelanggan}

Lokasi berpengaruh terhadap kepuasan pelanggan melalui keputusan pembelian, yang berarti bahwa lokasi yang strategis dapat meningkatkan kepuasan pelanggan, jika didukung dengan keputusan pembelian menggunakan pertimbangan yang tepat. Lokasi yang strategis mempengaruhi seseorang dalam menimbulkan keinginan untuk melakukan pembelian karena lokasinya yang strategis, terletak di arus bisnis, dan sebagainya. Dengan demikian bahwasanya penentuan lokasi menjadi suatu pertimbangan oleh pelanggan, dimana jika lokasi yang ditentukan sagat strategis maka pelanggan akan memutuskan untuk melakukan pemblian, namu jika lokasi yang dientukan tidak begitu strategis maka pelanggan akan lebih banyak mempertimbangkan keputusannya untuk melakukan pembelian.

\section{KESIMPULAN DAN SARAN}

\section{Kesimpulan}

Berdasarkan hasil penelitian yang telah dilakukan, maka peneliti dapat menarik kesimpulan sebagai berikut: 1). Lokasi berpengaruh terhadap keputusan pembelian, yang berarti bahwa semakin strategi lokasi dapat meningkatkan keputusan pembelian. 2). Lokasi berpengaruh terhadap kepuasan pelanggan, yang berarti bahwa lokasi yang mudah dijangkau dapat meningkatkan kepuasan pelanggan. 3). Keputusan pembelian berpengaruh terhadap kepuasan pelanggan, yang berarti bahwa pelanggan akan merasa puas apabila terdapat kesesuaian lokasi yang terjangkau. 4). Lokasi berpengaruh terhadap kepuasan pelanggan melalui keputusan pembelian, yang berarti bahwa lokasi yang strategi dapat meningkatkan kepuasan pelanggan apabila keputusan pembelian dilakukan spectral

\section{Saran}

Berdasarkan hasil penelitian dan pembahasan penulis memberikan saran sebagai berikut: 1). Lokasi perlu dipertimbangkan karena dapat mempengaruhi keputusan pembelian dan kepuasan pelanggan, dengan cara lokasi yang mudah dijangkau Untuk penelitian lebih lanjut, perlu untuk mengembangkan keputusan pembelian sebagai penguatan kepuasan pelanggan, dengan cara menambahkan variabel yang mempengaruhi kepuasan pelanggan. 2). Perumahan The Anggana by Adhi memberikan peta lokasi Dan gambar rumah pada saat pameran perumahan, seperti diberi pagar depan gratis, free BPHTB (Bea Pengalihan Hak atas Tanah dan Bangunan) bonus sepeda motor, TV Flat gratis, dan lainlain, sehingga dapat meningkatkan keputusan pembelian yang pada akhirnya menghasilkan kepuasan pelanggan yang akan merekomendasikan perumahan kepada orang lain. 3). Bagi peneliti lebih lanjut diharapkan dapat mengembangkan model penelitian ini dengan menambahkan variabel lain seperti Kualitas Layanan, Citra Perusahaan, dan Nilai Pelanggan yang mempengaruhi kepuasan pelanggan.

\section{DAFTAR PUSTAKA}

Alma, Buchari. 2007. Manajemen Pemasaran dan Pemasaran Jasa. Edisi Revisi. Bandung CV. Alfabeta. 
Amirullah. 2002. Perilaku Pelanggan. Yogyakarta: Graha Ilmu.

Anderson, Edvardson et al, 2000 Operations management : Strategy and Analysis, $4^{\text {th }}$ edition, Addison Wesley publishing company : Massachusset.

Azwar. 2001. Metodologi Penelitian Bisnis $1^{\text {st }}$ edition. Yogyakarta: Penerbit BPFE.

Bahri. Keputusan Pembelian dan Kepuasan Pelanggan Dipengaruhi Variabel Lokasi, Pelayanan, Kualitas Produk, Nilai Emosional, dan Disain Interior yang Berdampak pada Tingkat Pembelian. Jurnal Maksipreneur. Volume 8 No. 1: 60 - 80.

Brata, Baruna Hadi, Shilvana Husani dan Hapzi Ali. 2017. The Influence of Quality Products, Price, Promotion, and Location to Product Purchase Decision on Nitchi At PT. Jaya Swarasa Agung in Central Jakarta. Saudi Journal of Business and Management Studies. Vol-2, Iss-4B (Apr, 2017):433-445.

Dengah, Stefandy., Rumate, Vecky., Niode, Audie. 2013. Analisis Pengaruh Pendapatan Perkapita dan Jumlah Penduduk Terhadap Permintaan Perumahan Kota Manado Tahun 2003-2012. Jurnal Berkala Ilmiah Efieiensi, Vol. 14 (3), pp.71-81.

Ferdinand. 2006. "The Marketing Strategy Containum : Toward a Marketing Concept For 1990's, Management Decision 29 (1) : 7 13

Firdiansyah, Indra. 2017. Pengaruh Kualitas Pelayanan, Harga, Dan Lokasi Terhadap Kepuasan Pelanggan Pada Warung Gubrak Kepri Mall Kota Batam. Jurnal Elektornik REKAMAN (Riset Ekonomi Bidang Manajemen dan
Akuntansi) Sekolah Tinggi Ilmu Ekonomi Galileo. Volume 1 No 1: $1-9$

Freddy. 1996. "Riset Pemasaran ", Gramedia Pustaka Utama, Jakarta \& STE IBII

Ghozali, Imam. 2006. “ Aplikasi Analisis Multivariabel dengan Program SPSS". Semarang: Badan penerbit Undip.

Imam Arrywibowo dan Ayu Awaliyah, Analisis Pengaruh Harga Lokasi Bangunan dan Lingkungan terhadap Keputusan Pelanggan Membeli Rumah, di Perumahan Pelangi Grand Residence di Balikpapan. Jurnal Management dan Start Up Bisnis, Vol 1, Nomor 3, Agustus 2016376 - 381

Kotler, Philip and Keller, Kevin Lane. 2013. Manajemen Pemasaran, Jilid 1, Edisi 13, Jakarta: Erlangga.

Kottler, Philip. 2005. Manajemen Pemasaran, Jilid II, Edisi Kedua Belas. Jakarta: Erlangga.

Kotler, Philip. 2007. Manajemen Pemasaran. Cetakan Pertama. Edisi Keenam. Jilid Kesatu. Alih bahasa Jaka Wasana. Jakarta: Penerbit Erlangga.

Kotler, Philip \& Armstrong, Gary. 2008. Prinsip-prinsip Pemasaran. Jilid 1. Jakarta: Erlangga.

Kotler dan Keller. 2009. Manajemen Pemasaran. Jilid I. Edisi ke 13 Jakarta: Erlangga.

Lamb, Charles W., Joseph F. Hair, dan Carl McDaniel. 2001. Pemasaran. Edisi pertama. Jakarta: Salemba Empat..

Lovelock, Christoper. 2005. Manajemen Pemasaran Jasa. Kelompok Gramedia, Indeks, Indonesia.

Lupiyoadi, Rambat. 2008. Manajemen Pemasaran Jasa Edisi Kedua. Jakarta: Salemba Empat.

Malhotra, K., Naresh dan Satyabhushan Dash. 2009. Marketing Research: 
An Applied Orientation, 5th ed. New Delhi: Dorling Kindersley (India) Pvt. Ltd. Licences of Pearson Education in South Asia.

Mandey, Jilly Bernadette. 2013. Promosi, Distribusi, Harga Pengaruhnya Terhadap Keputusan Pembelian Rokok Surya Promild. Jurnal Emba. Vol. 1 No. 4: 95 - 104.

Noerchoidah. 2013. Analisis Pengaruh Harga, Kualitas Produk Dan Iklan Terhadap Brand Image dan Keputusan Pembelian Sepeda Motor Merek Kawasaki. Jurnal WIGA. Vol. 3 No. 1: 48-60.

Rahmawati. 2018. Pengaruh Harga dan Minat Beli terhadap Keputusan Pembelian Pelanggan Shopee. Jurnal Riset Sain Manajemen. Volume 2 No. 4: 143 - 150.

Schiffman \& Kanuk. 2007. Perilaku Pelanggan. Dialih bahasakan oleh Zulkifli Kasip. Edisi Ketujuh. Penerbit PT. Indexs.

Silalahi, Uber. 2009. Metode Penelitian Sosial. Bandung: PT. Refika Aditama.

Stanton, William J. 2006. Dasar - Dasar Manajemen. Jakarta: Mandar Maju.
Susanto, Andhika. 2013. The Influence Of Customer Purchase Decision On Customer Satisfaction And It's Impact To Customer Loyalty. Jurnal EMBA. Vol. 4 No.1: 16591666.

Swastha Basu, Dharmesta dan Irawan. 2008. Manajemen Pemasaran Modern, Yogyakarta: Liberty.

Tjiptono, Fandy. 2008. Strategi Pemasaran. Edisi III. Yogyakarta: Penerbit CV. Andi Offset. 2010. Service Management: Mewujudkan Layanan Prima. Yogyakarta: Andi Offset,.

Tresnanda, Dick, A., Arifin, Zainul., Sunarti. 2014. Pengaruh Bauran Pemasaran Terhadap Keputusan Pembelian Rumah (Survei pada Pelanggan Perumahan BluKid Residence Sidoarjo). Jurnal Administrasi Bisnis. Vol. 8 (1).

Wardhani, Widya., Sumarwan, Ujang., Yuliati, Lilik, N. 2015. Pengaruh Persepsi dan Preferensi Pelanggan terhadap Keputusan Pembelian Hunian Green Product. Jurnal Manajemen dan Organisasi. Vol. 6(1), pp.46-63. 